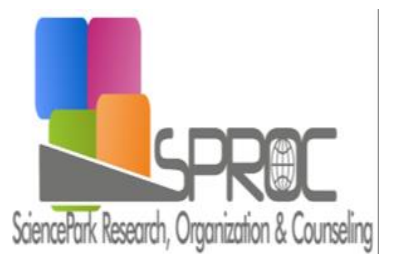

ç

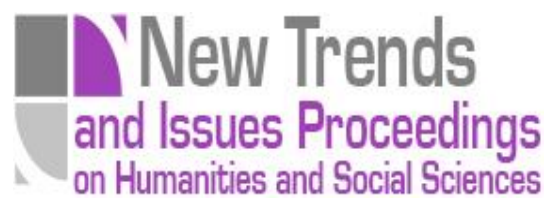

ç

\title{
Understanding of user evaluations on fun products
}

Saadet Akbay ${ }^{*}$,

$E$

Suggested Citation:
E

ç

ç

Abstract

ఢ̧

Ç Saadet Akbay, 
1.Introduction

Ç

Ç

Ç

Ç ఢ̧

Ç

2. The Study

2.1. Materials

2.2. Participants

2.3. Method and Procedure 


\subsection{Data Analysis}

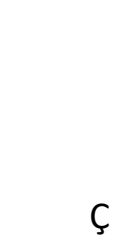

3. Results

3.1. Evaluating the most enjoyable product 
Table 1. Frequently mentioned constructs within the category of visual aspects ( $N=29)$ 


\subsection{Defining the term 'fun product'}

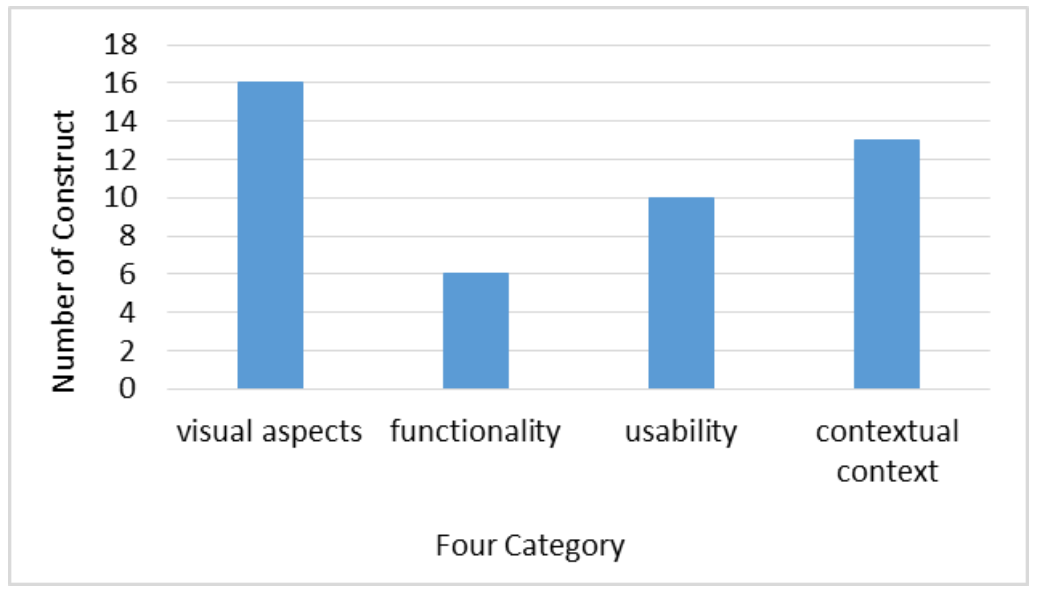

Figure 3. Frequency distribution of the constructs under four-category of the term 'Fun Product' 
Table 3. Frequently mentioned constructs within the category of visual aspects ( $N=29$ )

$$
\text { Construct }
$$
frequency $\%$

Table 4. Frequently mentioned constructs within the category of contextual content ( $N=29)$ 
4. Discussion and Conclusion

Ç 


\section{References}

ç

Ç Ç

Ç

H

Ç

$\mathrm{H}$

Ç

Ç

Ç 